\title{
The Concept of Digital Natives \& Digital Immigrants in Context of India
}

\author{
${ }^{1}$ Shweta Darbha, ${ }^{2}$ Prof. N. Sambasiva Rao \\ ${ }^{1} \mathrm{Ph} . \mathrm{D}$ Scholar, Dept. of Commerce \& Management Studies, Andhra University \\ ${ }^{2}$ Dept. of Commerce \& Management Studies, Andhra University \\ ${ }^{1}$ sbhagwat01@yahoo.co.in
}

\begin{abstract}
Abs tract: This article focuses on defining the digital immigrants and digital natives in context of India while tracing the advent of digital technology in India. The author has borrowed the concept of "Digital Natives and Digital Immigrants" from Marc Prensky and explored it further in context of India, digital technology adoption in public and private sector and the workforce belonging to the two groups of digital workforce. This article is based on the qualitative approach of a) literature review to understand the concept of Digital Natives and Digital Immigrants and 2) Further analyze these definitions to propose how the dig ital immigrants have adopted and adapted to the digital technologies, leveraging these in the private and public sector organizations while the digital natives are slowly joining the workforce in India. The article posits that unlike western nations, India embarked on its digital journey only in the last 20 years and has leap frogged through the technologicalchanges. The article further dwells on the impact of this digital journey on the business strategy, customer interactions and workforce itselfand the digital divide that impacts the social and organizational workforces.
\end{abstract}

Keywords: Digital Native, Digital Immigrants, Digital Divide, telecommunication

\section{INTRODUCTION}

Marc Prensky introduced the concept of Digital Natives and Digital Immigrants [1] more than a decade back in his article entitled Digital Natives, Digital Immigrants. Prensky defines Digital Natives as the generation who have grown up with new technology. He posits this generation with specific characteristics of having spent their entire lives surrounded and using computers, videogames, digital music players, cell phones, 24 by 7 access to internet and digital tools. Digital Natives think and process information differently and is used getting information on the World Wide Web at the press of a key rather than text books and libraries.

In contrast to the Digital Natives he defines Digital Immigrants are the generations who "were not born into the digital world but have, at some later point in our lives, become fascinated by and adopted many or most aspects of the new technology". Hence as is with any migration and adaptation, immigrants still continue to retain a certain degree of their "accent". By "Accent" Prensky is drawing a parallel to influence of the past on a new language we learn and still retain an accent from our mother tongue.

Prensky quiet correctly compares the advent of Digital technology as a "singularity"- an event which changes things so fundamentally that there is absolutely no going back.

This article is an attempt to review and define this concept of Digital Immigrants and Digital Natives in the context of India. The article presents a brief history of India's digital journey, the adoption of digital technologies in private and public sector thereby drawing a relation between the digital immigrants workforce who form the large percentage of the workforce, decision makers and users of these technologies while digital natives though are the smaller percentage in the workforce but are substantial in number as customers of these organizations.

\section{IMPACT OF DIGITAL TECHNOLOGIES ON INDIAN ORGANIZATIONS}

\subsection{B rief His tory of Advent of Digital Technology in India}

The late 1980s heralded the telecom revolution in India which enabled STD/ PCO booths to sprout at every corner in the country connecting the length and the breadth of the nation through fixed 
landlines. It was in 1995 that next major milestone of telecommunication was achieved with introduction of internet and mobile telephones. Department of Telecom (DoT) and its sub-divisions MTNL and BSNL managed the telecom sector. A series of reforms in the telecommunication sector enabled privatization of DoT (now called VSNL with TATA Sons owning 49\% stake), foreign investment in domestic telecom sector and private operators to enter the telecom sector. [2]

In 2000, the government further reduced the license fee for cellular services thereby creating the next wave mobile adoption across the nation. Today with an ever increasing subscriber base of more than 929 million, the Mobile telecommunications system in India is the second largest in the world. While the tariffs are lowest in the world. [3]

In 2010 the Third Generation (3G) spectrum was auctioned followed by Fourth Generation (4G) spectrum in 2015. Thus enabling mobile devices to connect to internet for constant data consumption.

As reported by Forbes Asia, by January 2016 India had crossed more than 1 Billion mobile subscribers. As per the latest report, IAMAI (Mobile Internet in India 2016) estimates India to have 371 million mobile internet users by June 2016.

Unlike western countries India started on its digital journey only in the last two decades or less. However, as is propounded by "Technology Leapfrog" theory [4][5][6], being a late entrant to the technological changes sweeping across developed nations, India leapfrogged through digital changes. "Technology leapfrogging" refers to the adoption of advanced or state-of-the-art technology in an application area where immediate prior technology has not been adopted. [7]

This enabled India to embark on its digital journey with the telecommunication revolution and IT \& IS (Information Technology and Information Services) sector becoming one of the largest software exporters. The IT-IS industry became the second largest sector creating millions of jobs for the Gen-X and Millennials [8][9][10][11] and creating opportunities , wealth and global organizations. This also introduced fast paced and multiple technological changes for the population at large and the workforce across all industries and sectors.

\subsection{Digital Immigrant and Digital Natives in Indian Workforce}

As established in the previous section, India's digital journey is merely that of last 20 years or less. Hence unlike western nations, it is only the millennials born after 1995 can qualify Digital Natives. The Digital Natives are not yet part of the workforce or are just making an entry in the workforce. However, this generation forms a decisive part of the consumer and customer base for most of the organizations and are the current target segment, who will engage with the organization in the coming years more than the Generation $-X$ or Baby Boomer generation. [8][9][10][11]

On the other hand more than $90 \%$ of the Indian workforce is Digital Immigrants, who are adopting and learning the digital technologies and it's parlance in different measures. The Generation X[8][9][10][11]and the early Millennials [8][9][10][11]are the most advanced amongst the Digital Immigrants as compared to Baby Boomers. While the Generation-X [[8][9][10][11] constitute mainly of the middle and senior management, it's the Baby Boomers who were and in some cases are still the executive heads and CXOs of the organizations. These Baby Boomers too have been at fore front of advent and adoption of digital technologies in organization and their workforce.

\subsection{Adoption of Digital Technologies in Indian Organizations}

In India the first wave of digital adoption within public and private sector was led by the Digital Immigrants. The first wave of introduction of digital solution to the workforce was through automation solutions, enterprise applications and industrial digital solutions.

The Indian government and private sector workforce have been a willing and diligent Digital Immigrants, learning, adopting and spearheading India's path on digital journey. Across government and private sector, technology adoption has been significantly robust and fast paced. Government sectors like Railways, Heavy Industry, Governance, Agriculture etc. have adopted digital solutions for higher productivity, efficiency, communication and collaboration. Private sectors like Manufacturing, Retail, travel and transport, education etc. have been equally willing to adapt to reap the benefits of advanced digital solutions.

However, the adoption rate has differed from sector to sector and so has the pace. So while administrative activities of education sector have adopted digital solution, the mode of teaching and interaction is still old school. Transportation might have adopted digital solutions for customer 
services (e.g ticket booking), however the wider operations still have old systems. The e-Governance initiatives started in 2006 by central government across India, however the pace and width of these initiatives is stalled by lack administrative zeal. Health care, agriculture, rural development areas

The Indian IT industry has been at the forefront of the private sector organizations to adopt and leverage digital technologies for the first wave of technocrat entrepreneurship in India. Infosys Technologies, Tata Consultancy services, Wipro and Cognizant Technology Services etc. were started by groups of Digital Immigrants who were not only early adopters of technology but evangelists who foresaw Indian workforce's potential to influence and drive the software industry not only India but worldwide.

Social networking, cloud computing, mobile technologies and data analytics are the second wave of digital adoption. It is the second wave of digitization that the Digital Native population of India has been really born in. Though they form a much smaller percentage of workforce currently, however as consumers and customers the digital natives are the next generation of consumers that organizations need to target. As workforce, it is this generation which will enable organizations to grow and succeed in the digital economies and technologies.

\subsection{Impact of Digital Adoption on Organizations: Customer Interactions and Workforce Engagement}

\subsubsection{Customer Interactions}

The impact of digital technologies on organization has not only been with respect to the workforce being digital immigrants or digital natives, but has impacted their customers too. The customer base itself is widely divided between the digital immigrants and digital natives engaging with organizations, products and services with different degrees of digital knowledge, adoption and expectations.

In this section we dwell on these two aspects of an organization: Customer Interaction in the digital economies [12] and Workforce engagements.

The first wave of digital solutions enforced and required organizations to adopt internet and ensure their presence through websites, customer relationship management solutions for deeper customer insights and call center support. These technological changes were mainly adopted by the Generation$X$ [8][9][10][11] customers, who though were mostly digital immigrants however were at the forefront of the digital changes being adopted across world and India.

However the second wave of digital technology changes requires organizations to enable mobile websites, social media interactions and mobile commerce. The Digital native customers are at the forefront of these technological changes. They wield mobile devices sometime more efficient than the organizations themselves have, they use social media to discuss about everything which includes commenting on their purchases, experiences with brands and are comfortable being "trollers" or being trolled.

The challenge for the business strategists of the organizations lies in the fact that being digital immigrants they mostly neither use these technologies themselves nor have experience to leverage these for interaction with their customers. Face book pages of organizations do not get updated for months, Twitter handles are created however do not get used often and mobile websites use experience is yet to evolve.

Mobile commerce has created disruptions unlike the internet wave with new Indian and MNC corporations like Flip kart, Pay TM and Amazon to name a few have created.

The CXOs and senior management needs to revisit their strategies to ensure the organizations understand these digital technologies which their digital native customers are leveraging for all their interactions.

\subsubsection{Workforce Engagement}

All organizations across all sectors find themselves in a very unique position where they have the Baby Boomers, Generation X and Millennials [8][9][10][11] all working together. To add to this uniqueness is the adoption and understanding of the digital technologies across these generations.

The late Millennials are the true Digital Natives and are yet to become substantial numbers within the workforce while the rest of the workforce is Digital Immigrants. However the divide between the Digital Immigrants is starkly marked with difference in their capabilities to learn and adapt to digital 
technologies and mirror the behavior of Digital Natives rather Digital Immigrants.

This has created challenges in areas of the workforce management:

\section{- Communication\& Interactions}

Digital Natives are used to the social media, mobile devices and ubiquitous connectivity. They expect organizations to enable email access through mobile devices, allow social media interactions through organizational social channels like Face book, twitter or Instagram. With constant access to internet through ubiquitous connectivity they expect flexible policies to work from anywhere at any time.

The organizations will need to formulate their mobile policies for BYOD (Bring Your Own Device), social media and security policies to enable connectivity. Restricted access or controls are bound to create friction and employee dissatisfaction.

\section{- Learning \& Development}

The class based pedantic style of learning and development processes will have to evolve to engage the digital natives who are used to more interactive and short duration interactions.

The material and manuals cannot be large tomes rather will need to digital, mobile friendly with ease to access. Expecting a workforce to sit in class room and learn by rote will not be successful in the new digital world. The digital immigrant instructors will have to ensure they enhance their technology skills to interact with Digital natives through various technological options lest they lose their attention.

\section{CONClusion}

"The Only Thing That Is Constant Is Change"- Heraclitus.

Independence of India from British rule in 1947 and the economic liberalization in 1991 were the two singular changes that have defined India as a sovereign and one of the fastest growing economies of the world respectively. The next wave of change is the pan India adoption of digital technologies, to enable its current workforce and the next generation to play a truly global role while enabling the growth of Indian social - economic fabric leveraging technology.

Indian workforce is uniquely placed with the Generation $X$ [8][9][10][11] having joined the workforce as the country started with its Digital Journey. Thus the digital divide amongst the Digital Natives and Digital Immigrants [1] is not enormous. However clearly with digital technologies evolving rapidly, the future workforce will be more advanced in their technology capabilities and hence organizations have to ensure that the current workforce is not only exposed to new technologies, but the organizations adopt these technologies to enhance their productivity, workforce cohesiveness and also for successful interaction with ever evolving digital native customer base.

\section{REFERENCES}

[1] Digital Natives, Digital Immigrants By Marc Prensky (2001), On the Horizon, MCB University Press, Vol. 9 No. 5, October 2001

[2] Vanita Kohli (14 June 2006). The Indian Media Business. SAGE. pp. 189-. ISBN 978-0-76193469-1.

[3] Dash, Kishore. "Veto Players and the Deregulation of State-Owned Enterprises: The Case of Telecommunications in India"

[4] Antonelli, C. (1991). The diffusion of advanced telecommunications in developing countries. Paris: OECD.

[5] Lamberton, D. (1994, November). The information revolution in the Asian-Pacific region. Asian-Pacific Economic Literature, 8(2), 31-57.

[6] Mody, A., \& Dahlman, C. (1992). Performance and potential of information technology: An international perspective. World Development, 20(12), 1703-1719.

[7] Michelle W. L. Fong (2009). Victoria University, Australia Technology Leapfrogging for Developing Countries

[8] Adams SJ. 2000. Generation X: how understanding this population leads to better safety programs. Professional Safety 45: 26-29. 
[9] Jurkiewicz CE, Brown RG. 1998. GenXers vs. boomers vs matures: generational comparisons of public employee motivation. Review of Public Personnel Administration 18: 18-37.

[10] Kupperschmidt BR. 2000. Multigenerational employees: strategies for effective management. The Health Care Manager 19: 65-76.

[11] Smola, K.W., Sutton, C.D., 2002. Generational differences: revisiting generational work values for the new millennium. Journal of Organizational Behavior 23, 363-382.

[12] Tapscott, Don (1997). The digital economy: promise and peril in the age of networked intelligence. New York: McGraw-Hill. ISBN 0-07-063342-8.

\section{AUTHORS' BIOGRAPHY}

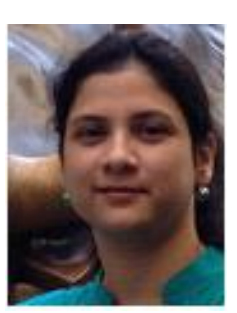

Shweta Darbha, she received her MBA degree from Symbiosis Center for Manag ement \& HRD (2002), India. She is currently pursuing her Ph.D. (Executive) with Andhra University. Shweta has over 14 years of work experience inclusive of 9 years of products and solutions management experience and 5 years of business consulting and customer management experience in top-tier IT product and services companies across Digital products \& Solutions, SMAC solutions and platforms, product portfolio management, Infrastructure Management products, Customer Relationship Management (CRM), Customer Data Management (CDM), Marketing and Loyalty program management.

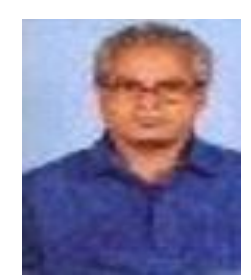

Prof. Rao, is working in the Department of Commerce and Management Studies, Andhra University, Visakhapatnam for the last 30 years. He finished his MBA from Andhra University. His area of research is Human Resource Management and Marketing. He is associated with all HR national professional bodies like HRD Network, ISTD, NIPM AIMA and occupied various positions at chapter level and at national level. He organized more than ten national conferences and attended 50 national conferences as panel speaker and chairing the sessions. In addition to teaching and consultancy, he served in the University in various administrative positions. He has written two books. 